\title{
Knowledge Production-Consumption: A Comparative of Two Famous Online Preachers in Indonesia and the Philippines
}

\author{
C B Tenorio ${ }^{1}, \mathrm{H} \mathrm{Jubba}^{2}$, Z Qodir ${ }^{3}$, M Hidayati $^{4}$ \\ Department of Islamic Politics-Political Science, Universitas Muhammadiyah Yogyakarta, \\ Indonesia ${ }^{1,2,3,4}$ \\ \{christinebtenorio@gmail.com¹, hasse@umy.ac.id ${ }^{2}, \underline{\text { zuliqodir@umy.ac.id }}$, megahidayati@umy.ac.id ${ }^{4}$ \}
}

\begin{abstract}
The manners of expressing religious identity have changed rapidly over the past decade. It resulted in the emergence of the online global community. The also known 'networked religion' is used to recognize how religion functions online. This study applies comparative research intended to explore the distinction between two popular online preachers in Indonesia and the Philippines, i.e. Abdul Somad and Cardinal Luis Antonio Tagle respectively. Through their social media, it analyses their popularity, religious spectacle, and political issues. A comparative analysis between the two popular preachers gives findings of the current internet and religious situations in the Philippines and Indonesia. First, that Indonesians are more susceptible to digital religious preaching compared to the Filipinos. Second, both the preacher's religious spectacles touched and convinced the heart of the Filipino and Indonesian people through their words and wisdom as the product by their strategy of unique preaching style and charisma. Third, the Indonesian religious preacher is more vulnerable to political issues. The Philippine religious preacher's influence is limited by the law of the country's separation of Church and the state.
\end{abstract}

Keywords: Network Religion, Social Media, Abdul Somad, Card. Antonio Tagle

\section{Introduction}

The Internet for almost three decades has been utilized as a discussion for traditional religious beliefs and as a space for spiritual rituals. In the early 1980s, ethical use of the Internet was able to trace. Bulletin Board System (BBS) was the first religious-orientated activity based upon the Rheingold documents [1];[2]. These were under a "create your own religion" heading on the discussion area of CommuniTree. Usenet, during the 1980s period, was online religious discussion surfaced. The religious computer enthusiasts that time began to explore "ways to use this new means of communication to express their religious interests" [3]. The first networked forum for discussion on the religious, moral and ethical implications of human actions was known as "net.religion" [4]. Thus, in the mid-1980s it steadily grew when it fragmented into the hierarchies of "alt.religion," "soc.culture," "alt.philosophy," "talk. Religion" and "soc.culture," during the restructure of Usenet. Many other religious computer enthusiasts throughout the 1980s designed online groups committed to their specific religion such as the first Christian email newsletter "net.religion.Jewish Usenet group and "United Methodist Information" [1];[2]. Furthermore, increasing numbers of religious groups and 
mailing lists commenced emerging online in the 1990s such as H-Judaic (www.hnet.org/ judiac/), BuddhaNet (www.buddhanet.net) and Econet, an ecumenical Christian email listserve (www.ecunet.org) [5]. Furthermore, religious practitioners, as well as a researcher, started to investigate the unique scope and forms of religion all over the internet [6]. Research on religion online has not been isolated to one methodological or discipline approach [7]. The Internet refers to networking computer technology including the World Wide Web and other platforms or techniques such as chat rooms and messaging that are connected by the "network of network" [7]-[10]

\section{Method}

The term "religion online" is used to describe a form of traditional and non-traditional practices and discourses when it is visible on the Internet (H. A. Campbell, 2013). In this review, the researcher takes two religious authorities that have different backgrounds to give enough comprehensive religious discourse on the internet. This study applies comparative analysis intended to explore the distinction between two popular online preachers in Indonesia and the Philippines, namely: Abdul Somad and Cardinal Luis Antonio Tagle. Moreover, through their social media, it is interesting to analyze their popularity, religious spectacle, and political issues. Thus, each of these approaches implies their ideas.

\section{Result and Discussion}

\section{Popular Online Preacher in Indonesia and Philippines}

\section{Abdul Somad Batubara: Brief Profile}

Abdul Somad Batubara or Somad, in two years, has made an astonishing transformation from a small-town lecturer to Indonesia's most prominent digital preacher. Somad is an Indonesian Islamic preacher and ulama from Asahan, North Sumatra. Al-Washliyah is a school-based on Quranic memorization, where he went through his elementary education [11]. In 1990, after graduation, he moved to continue his education at Mu'allimin al-Washliyah in Medan. Consequently, Nurul Falah Higher Madrasah is where he studied and returned to Riau after graduation in 1993. He was among 100 students who granted a scholarship by the Egyptian government to the Indonesian students studying at Al-Azhar University in 1998 [12]. In line with that, the Moroccan government in 2004 provided him with an award for postgraduate education at Dar al-Hadith al Hasaniyyah Institute [7];[12]. It yearly receives 20 students, constitutes of five foreigners and 15 Moroccans. Thus, Somad is a product of two prestigious Islamic universities Dar al-Hadits al-Hasaniyyah Institute in Morocco and Azhar University in Egypt. In his sermons, he often states and places his master's degree (LC, MA) intentionally in front of his name to remind people of his credentials. In addition, Somad's use of Arabic is exceptional; knowledge of Islamic history and Islamic texts are something that attracts people to Somad [7];[13];[11]. 


\section{Popularity of Abdul Somad}

Abdul Somad's popularity was brought by his preaching events that can allure crowds of tens of thousands, and he is Indonesia's highest-ranked digital preacher. In line with that, Somad garnered over 9.6 million Instagram followers. Thus, Abdul Somad's fame was relatively by chance [14]. At the Syarif Kasim State Islamic University, Somad as a lecturer had translated and published several books about Islam. And he was also an occasional preacher at Islamic study groups in Riau. On the other hand, he was famous as a preacher in his province. Somad wasn't an active online user apart from his blog that had a limited audience [11]. Not until his fate was changed when a video of one of his sermons scattered widely on Facebook and Youtube in May 2017 [12]. Somad gained a busy preaching schedule almost immediately following the release of the video. Thus, in 2018, the attention of international media interested to him, when he claimed that Muslims buying Starbucks coffee would go to hell because of the company's LGBT support community [7];[11];[14].

Thus, it is subject to dispute on how much Somad earns from his preaching. A netizen, Gunawan Abu Syafiq II, claimed that Somad charges up to Rp60 million (A\$6,000) per sermon. And yet, Somad asserted that he never charges a fixed price. Tafaqquh, a local organization in Riau, supported Somad's digital earnings. In March 2018, his official YouTube channel Tafaqquh Video received a Silver Play Button from YouTube for gaining a 100,000 subscriber [7], [11]. In February 2019, a Gold Play Button was received for achieving one million subscribers. Thus, Somad's current subscriber is 1,449,026. Social Blades, a social media analytics service, stated that Tafaqquh video alone makes between US\$41,000$\$ 651,600$ annually [11]. However, it is likely around US\$75,000-\$100,00 earnings of Tafaqquh Video based upon the analyst familiar with online advertising in Indonesia [14], [12].

\section{Religious Spectacle of Abdul Somad}

Somad's celebrity label surfaces from the religious spectacle he establishes. Somad adopts humor, popular culture, and Q \& A approach to everyday life topics. He created the persona of kampung preacher with a sense of belonging who appeals to people's desire to reconnect that is inherent with the notion of the kampung. Somad's appearance described as modest and simple [7], [13]. A stage repertoire is Somad's oratory style; he employs sound effects that make him sound like a Qur'anic verse rapping, and popular song lyrics and Malay Pantun (poetic rhymes) [12]. He uses high and low tones speaking in his Malay accent with an authoritative tone and his rapping. Somad's style finds its foundation in the culture and traditional medicine men in the Sumatra [14].

\section{Political Issues of Abdul Somad}

In late 2017, Somad's popularity increased his disappointment with the Jokowi government. Somad was accused as an Islamist radical and thus dangerous to the state. Hence, Yaqut Cholil Qoumas accused Somad of being implicated in Hizbut Tahrir Indonesia (HTI), an organization that the Jokowi government banned in July 2017 [11]. Along these lines, a group of about 100 Ormas (community organization) in December 2017 surrounded Somad's hotel in Bali and forced him to sing Indonesian Raya or the Indonesian national anthem. Also, 
Somad was deported of the misused of his visa by the Hongkong government [14], [12]. In July 2018, Somad's name floated as a potential vice-president candidate to support Prabawo Subianto in the presidential race of 2019. Publicly, Somad rejected to enter politics, saying that he wanted to focus on his activities of dakwah (preaching) [7], However, Somad made a sudden endorsement of Prabowo in the final days of the election campaign. He was critical in pushing conservative swing votes to Prabowo at the last minute, said some observers [7], [11], [14]. Thus, Somad's endorsement of Prabowo produces problematic, following Jokowo's election. Because Somad was accused of breaching the neutrality required by the public service code of conduct as a lecturer at a State University, Somad is still a public servant [12].

\section{Cardinal Luis Antonio Tagle: Brief Profile}

On the $21^{\text {st }}$ of June 1957, in Manila Luis Antonio Gokim Tagle was born to a Chinese mother. At St. Joseph seminary Manila, he studied philosophy and graduated from Athenaeum of the University of Manila. On the 27thof February 1982, he has ordained a priest for Archdiocese of Manila [15]; [16]. In parishes ad seminaries for some time he has done some ministry in one which he was rector. In 1987-1991, he was sent to the Catholic University of America in Washington, D.C to complete his studies [7], Thus, defending his thesis on the notion of episcopal collegiality according to the Second Vatican Council and the influence of Pope Paul VI he received his doctorate in Theology. In the International Theological Commission in 1997, he was appointed as a member [8], [16]. In four seminaries, he then worked in various parishes and taught theology. In some years on the $22^{\text {nd }}$ of October 2001 , Pope John Paul II appointed him as bishop of Imus, a diocese of 2.6 Million Catholics. He was appointed Archbishop of Manila on the $13^{\text {th }}$ of October 2011. Cardinal Tagle is a theologian [8], [15].

\section{The popularity of Cardinal Luis Antonio Tagle}

The Word Exposed was Cardinal Tagle television program that has been running in the Philippines since 2008. There, he comments on the reading of the Mass for the following Sunday each week. Cardinal Tagle is also the most popular cardinal on Facebook with 531,629 likes. His Facebook account was managed by Jesuit Communications Foundation [17], [8], [16]. As well as being an academic, he is also a singer and composer. On YouTube, there are some of Cardinal Tagle Christian musical compositions that he performs himself. Thus, if the College of Cardinals had a rock star, in the Philippines, it would be Cardinal Luis, Antonio Tagle [8]. On Facebook, he is enormously popular and the youngest of the leading contenders to be pope. He was known for tooling around the streets of Manila on his bike, inspiring liturgies, delivering charismatic and welcoming the homeless to the dinner table [8], [16]. Perhaps because of his relative youth, it diminishes his chance on the long reign of St. Peter's throne [7], [17]. But, it also made the Cardinal the baby-faced among the most out of the box choices and a favorite. Cardinal Tagle was widely known in the Philippines by his nickname "Chito". Tagle is media savvy, regularly appearing on religious talk shows and becoming a YouTube sensation for his dulcet singing solos [7]. 


\title{
Religious Spectacle of Cardinal Luis Antonio Tagle
}

\begin{abstract}
Although the popularity of Cardinal Tagle is ironically was quite shy when he was younger. According to the Philippines Daily Inquirer, he said: "I've never been the active type. Even my teachers from grade school and high school will tell you: 'Ah yes Chito, he's always quiet." [15]; [7]. He is held in high esteem by his fans and media. Thus, one of the administrators of the Facebook page of 100\% Katolikong Pinoy ("100 percent Filipino Catholic), said one of his strengths in dealing with media. Both traditional and social media are utilized by Cardinal Tagle, making him as fans, a media darling, critic coin, and he is known for his piety and humility[8], [16]. In line with that, despite the laudable traits of Cardinal Tagle his propensity to cry in public could count against him at the conference. Last November, when he received the red hat, he broke down in tears. "A leader of the Church can be emotional at times but not all the time," Maccabeus say [15];[17].
\end{abstract}

\section{Political Issues of Cardinal Luis Antonio Tagle}

President Duterte, winning the presidency, launched an unprecedented war on illegal narcotics with the promise to kill tens of thousands of criminals. Among the few voices that denounce the deaths is the Catholic Church in spite of the popularity of the Philippines president of the polls that reveals [7];[13];[17]. In response to criticisms of extrajudicial killings, Duterte repeatedly launched vigorous attacks on priests and bishops [17]. Archbishop of Manila Card. Luis Antonio Cardinal Tagle invites the government to dialogue: "The drug problem should be reduced to a political or criminal problem. It is a humanitarian issue that affects us all." "Remember the words that God said to Cain, who had killed his brother Abel: Your brother's blood cries out to me from the soil (Genesis 4:10)." Thus, Card. Luis Antonio Tagle invites Catholics of his diocese to reflect, act and pray on the escalation of the war against illegal drugs led by the government of the Philippines [7]; [16]. The Archbishop of Manila invites everyone to conquer evil with good (Romans 12:21) and save the lives of people most defenseless to drug addiction: the poor, young people and the unemployed [8];[15];[17].

\section{A Comparative Analysis}

Table 1 shows the comprehensive distinction between Somad and Card. Tagle through their popularity, religious spectacle, and political issues. The researcher intends to compare and contrast the Indonesian famous religious preacher. Since Indonesia is a Muslim dominated country, the researcher chooses a Muslim religious preacher. On the other hand, since the Philippines is a Christian dominated country, the researcher selects a catholic famous religious preacher. So, the distinction focuses on an analysis between a Muslim and Christian popular religious preacher. 
Table 1. Abdul Somad Batubara \& Cardinal Luis Antonio Tagle

\begin{tabular}{|c|c|c|c|}
\hline Concepts & Abdul Somad & Card. Luis Tagle & Sources \\
\hline Popularity & $\begin{array}{l}\text { 9.6 million Instagram followers } \\
\text { 1,449,026 YouTube subscribers } \\
523,994 \text { Facebook likes }\end{array}$ & $\begin{array}{l}\text { 531, } 629 \text { Facebook likes } \\
\text { Word Exposed - Tagle } \\
\text { television program }\end{array}$ & $\begin{array}{l}{[14] .[17]} \\
{[15]}\end{array}$ \\
\hline $\begin{array}{l}\text { Religious } \\
\text { Spectacle }\end{array}$ & $\begin{array}{l}\text { Q \& A format is Somad's } \\
\text { preaching style that allows him } \\
\text { to personalize his sermons } \\
\text { through a more intimate two- } \\
\text { way dialogue. This concedes } \\
\text { him to speak with an array of } \\
\text { questions where he can express } \\
\text { that Islam has an answer for } \\
\text { everything. }\end{array}$ & $\begin{array}{l}\text { Card. Tagle's strength is } \\
\text { dealing with media that } \\
\text { employed both traditional } \\
\text { and social media making } \\
\text { him a media darling and } \\
\text { known for his piety and } \\
\text { humility. He is also a singer } \\
\text { and composer. }\end{array}$ & $\begin{array}{l}{[16]} \\
{[8]} \\
{[11]}\end{array}$ \\
\hline $\begin{array}{l}\text { Political } \\
\text { Issues }\end{array}$ & $\begin{array}{l}\text { - Somad was accused as an } \\
\text { Islamist radical } \\
\text { - Somad was implicated in } \\
\text { Hizbut Tahrir Indonesia } \\
\text { (HTI) } \\
\text { - Somad was also deported of } \\
\text { the misused of his visa by the } \\
\text { Hongkong government } \\
\text { - Somad's endorsement of } \\
\text { Prabowo, accused of } \\
\text { breaching the neutrality } \\
\text { required by the public } \\
\text { service code. }\end{array}$ & $\begin{array}{l}\text { Card. Luis Antonio Tagle } \\
\text { invites Catholics of his } \\
\text { diocese to reflect, act and } \\
\text { pray on the escalation of the } \\
\text { war against illegal drugs led } \\
\text { by the government of the } \\
\text { Philippines. }\end{array}$ & $\begin{array}{l}{[7]} \\
{[12] .}\end{array}$ \\
\hline
\end{tabular}

Card. Tagle and Somad have similarities when it comes to having high educational attainment and obtaining a degree in a prestigious university. The two religious preachers also are academicians in their community universities. But they differ how they become popular. His preaching events brought Somad's popularity and marked as Indonesia's highest rank digital preacher. Compared to Card. Tagle, his popularity boosted when he was the youngest of the leading contenders to be a pope. Along these lines, Somad is much more prevalent on the internet or digital compared to the Cardinal. Somad garnering 9.6 million Instagram followers, 1,449,026 YouTube subscribers and 523,994 Facebook likes. Compared to Cardinal Tagle, the most popular Catholic preacher in the Philippines who only has a 531, 629 Facebook likes and Word Exposed a Card. Tagle's television program. Thus, I argue that Indonesian is more susceptible to digital religious preaching compared to the Filipinos.

Thus, focusing on their religious spectacle, Somad's strategy was known for his Q \& A preaching style that allows him to personalize his sermons through more intimate two-way 
dialogue. Compared to Card. Tagle, his religious spectacle brought by his well-known piety, humility and the Cardinal is a good singer and composer. Hence, I argue that both the faithful preachers, religious spectacles touch and convinced the heart of the people. In line with that, their words and wisdom was the product by their strategy of unique preaching style and charisma. Lastly, their political issue Somad has more political conflicts compared to Card. Tagle. Somad accused as an Islamist radical, implicated in Hizbut Tahrir Indonesia (HTI), deported of the misused of his visa by the Hongkong government and endorsement of Prabowo charged with breaching the neutrality required by the public service code. Card. Tagle Filipino people and the government criticize him when he takes part in the war against illegal drugs led by the government of the Philippines. Furthermore, the reason that religious preacher in the Philippines was criticized when involving government activities because of law that stated under the Philippines constitution. The separation of Church and State shall be inviolable under (Article II, Section 6). Thus, I argue that Indonesian religious preachers are more vulnerable to political issues. Because compared to the Philippine religious preacher influence are limit by the law of the country's separation of Church and the state.

\section{Conclusion}

For almost three decades, the Internet has been used as a discussion for traditional religious beliefs and a space for spiritual rituals. The trend within religious practices online provides valuable insight into the nature and perceptions of spirituality and sociality online. Thus, religious practitioners and researchers started to investigate the unique scope and forms of religion all over the internet. Scholars started to document diverse ways in which religious groups and users were engaging in the Internet [6];[18];[19]. Studies of religion online, over time, have been increasing to investigate the struggle of power in religious organizations due to a reinterpretation of ancient rituals and web use. A comprehensive distinction between two religious authorities that have different backgrounds can give enough religious discourse on the internet. The two famous online preachers in Indonesia and the Philippines, namely: Abdul Somad and Card. Luis Antonio Tagle. A comparative analysis between the two popular preachers gives findings of the current internet and religious situations in the Philippines and Indonesia. First, that Indonesian's are more susceptible to digital religious preaching compared to the Filipinos. Second, both the religious preachers' religious spectacles touched and convinced the heart of the Filipino and Indonesian people through their words and wisdom as the product by their strategy of unique preaching style and charisma. Third, Indonesian religious preacher is more vulnerable to political issues. Because compared to the Philippine religious preacher influence are limit by the law of the country's separation of Church and the state.

\section{References}

[1] H. Campbell, "Religion and the Internet," vol. 25, no. 1, pp. 1-44, 2006.

[2] H. A. Campbell, "Religion and the Internet: A microcosm for studying Internet trends and implications," New Media Soc., vol. 15, no. 5, pp. 680-694, 2013, doi: https://doi.org/10.1177/1461444812462848.

[3] D. Lochhead, Shifting realities: Information technology and the church. Geneva: WCC Publications, 1997. 
[4] M. T. Ciolek, "Online Religion: The Internet and Religion." 2004.

[5] D. Farrington, "Ecunet: Our history. Ecunet.," 1993.

[6] B. Brasher, "Give me that online religion. Choice Reviews Online," vol. 39, no. 2, 2013, doi: https://doi.org/10.5860/choice.39-0876.

[7] A. Falola, "Cardinal Tagle: A Filipino hopeful for pope," 2013. .

[8] Alphalife, "Lusi Antonio Tagle Net Worth \& Biography," 2018. .

[9] H. A. Horst, "HORST v20 New Media Technologies in Everyday Life," Technology, pp. 1-21, 2011.

[10] J. Y. Hui, "The internet in Indonesia: Development and impact of radical websites. Studies in Conflict and Terrorism," vol. 33, no. 2, pp. 171-191, 2010.

[11] \& S. Gultom., "Abdul Somad: ustadz jaman now," 2019.

[12] T. \& Fadli, "It takes no edict. Surge in piety gives rise to sharia-inclined society in Indonesia," 2019. .

[13] G. Fealy, "Consuming Islam: Commodified Religion and Aspirational Pietism in Contemporary Indonesia," Expressing Islam, pp. 15-39, 2018.

[14] Rianto, "A preacher says Starbucks customers will go to the hell - the rise of Indonesia's new generation of preachers?," 2018. .

[15] Catholic Biblical Federation., "Card. Lusi Antonio Tagle," 2019. .

[16] R. Obordo, "The men who could be pope: Cardinal Luis Antonio Tagle," 2013.

[17] I. Fernandes, "Cardinal Tagle calls for "meaningful' religious vocations," 2016. .

[18] C. Ess, "Critical thinking and the Bible in the age of new media," 2004. .

[19] M. NightMare, "Witchcraft and the Web: Weaving pagan traditions online," 2001. 